\title{
Uropatía obstructiva litiásica con rotura de fórnix
}

\author{
Janeiro Pais JM, Casas Agudo VP, Ruibal Moldes M, Martínez Breijo S, Chantada Abad V, \\ González Martín M.
}

Servicio de Urología. Hospital Juan Canalejo. La Coruña.

Actas Urol Esp. 2007;31(10):1199

$\mathrm{V}$ arón de 56 años sin antecedentes de interés que ingresa con cuadro de cólico nefrítico izquierdo. En la radiografia simple de abdomen se visualizan varias calcificaciones radiopacas subcentimétricas, alguna de las cuales podría encontrarse en uréter distal derecho y corresponder a una litiasis (Fig. 1). Tras el ingreso se objetiva persistencia del dolor y un discreto empeoramiento de la función renal (Creatinina 1,6), manteniendo el resto de parámetros analíticos dentro de la normalidad.

Se le realiza UIV en la que se observa una rotura de fórnix calicial en riñón derecho, con posible litiasis en uréter distal (Fig. 2).

Se realiza la cistoscopia y se observa asomando por el meato ureteral derecho un cálculo enclavado, por lo que decidimos intentar su extracción mediante pinzas de cuerpo extraño, saliendo con dificultad un cálculo de unos $0,5 \mathrm{~cm}$ y tras él abundante orina con restos litiásicos milimétricos y gran cantidad de fibrina (Fig. 3. Secuencia endoscopia).

Se intenta ascender doble $\mathrm{J}$ no avanzando debido el edema perimeatal. Se desiste ante el riesgo de perforación.

Se realiza nueva UIV a los 3 días de la extracción del cálculo, observándose ausencia de fugas de contraste fuera de la vía urinaria, con una mínima ectasia en porción pélvica del uréter derecho y persistencia de calcificaciones que podrian corresponder a flebolitos (Fig. 4).

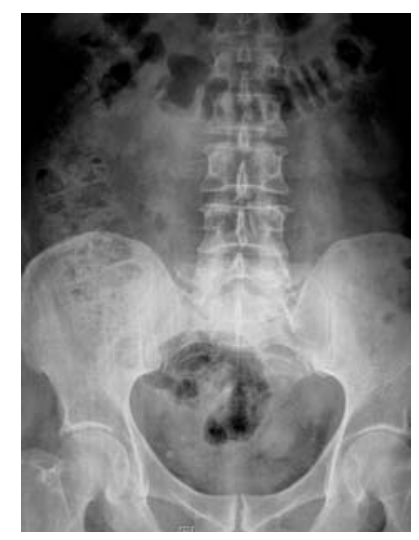

FIGURA 1

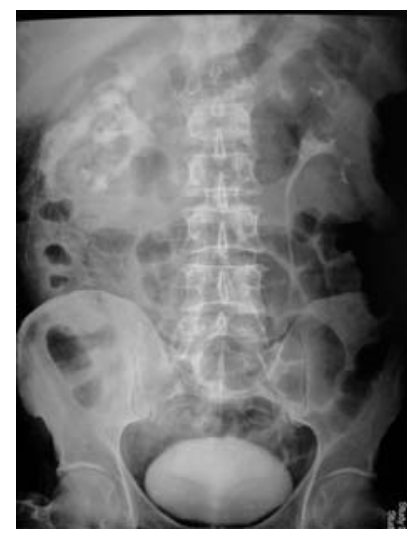

FIGURA 2
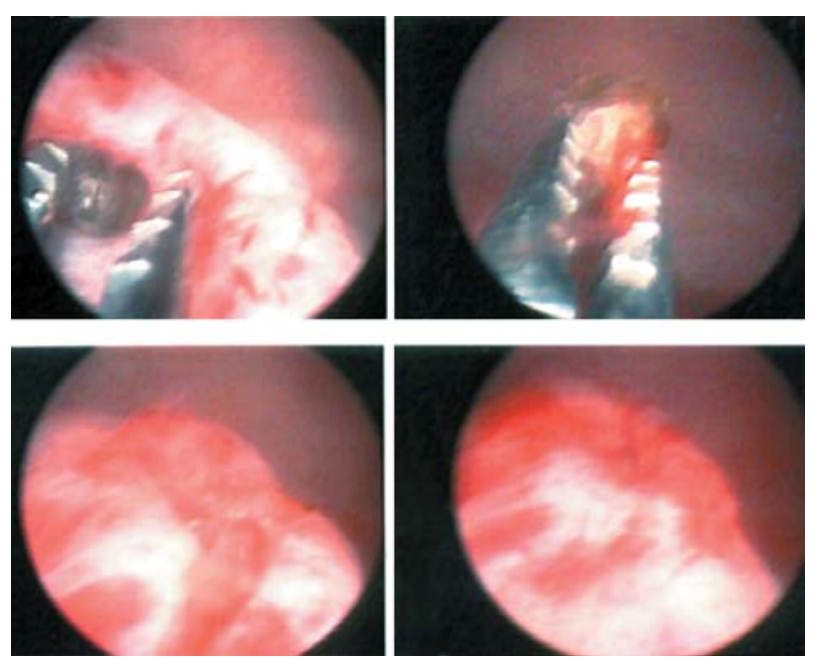

FIGURA 3

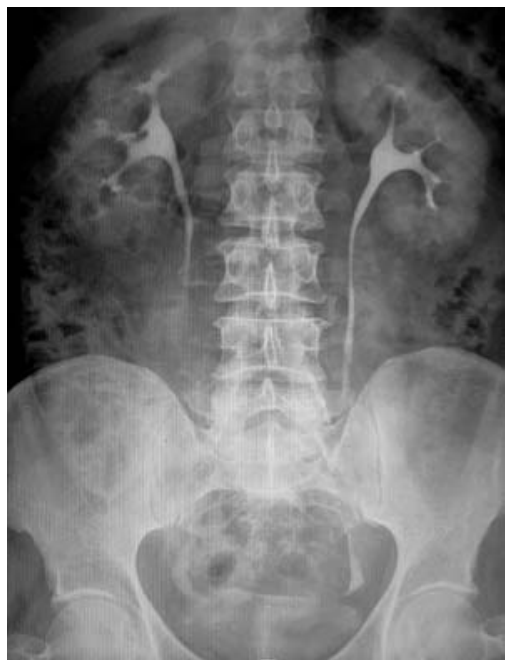

FIGURA 4

El paciente fue dado de alta asintomático, con la función renal normalizada, y actualmente sigue controles en la Unidad de Litotricia de nuestro Servicio.

Correspondencia autor: Dr. J.M. Janeiro Pais

Servicio de Urología. Hospital Juan Canalejo. Xubias de Arriba 84 15006 A Coruña. Tel.: 981178000

E-mail autor: janeiropais@canalejo.org

Información artículo: Imágenes en Urología

Trabajo recibido: octubre 2006

Trabajo aceptado: noviembre 2006 